3. Молодіжний центр «START» Уманського державного педагогічного університету імені Павла Тичини URL: https://youthcenters.net.ua/ molodigniy-tsentr-start/ (дата звернення: 10.07.2021)

4. Національний педагогічний університет імені М. П. Драгоманова URL: https://npu.edu.ua/novyny/podii/zahalnuniversytetski/studentyvolontery (дата звернення: 08.07.2021)

5. Університетський волонтерський загін «АКОРД» переміг у міському конкурсі «Волонтер року» URL: http://pnpu.edu.ua/news/ universytetsjkyj-volontersjkyj-zaghin-akord-peremigh-u-misjkomukonkursi-volonter-roku.html (дата звернення: 10.07.2021)

DOI https://doi.org/10.30525/978-9934-26-114-5-28

\title{
МОРАЛЬНІ ЗАДАЧІ ЯК ЗАСІБ ФОРМУВАННЯ В УЧНІВ ПІДЛІТКОВОГО ВІКУ ЦІННІСНОГО СТАВЛЕННЯ ДО ПРИРОДИ
}

\author{
Юркова Т. Ф. \\ доиент кафедри педагогіки, психології й освітнього менеджменту \\ імені проф. С. Петухова \\ Херсонський державний університет \\ м. Херсон, Украӥна
}

Сучасна педагогічна наука презентує досить об’ємну класифікацію методів виховного впливу, ефективне використання яких дає змогу будувати процес формування в підлітків ціннісного ставлення до природи на принципі поступового посилення самостійного творчого початку, орієнтувати їх на кращі зразки життєдіяльності в природі.

Стосовно проблеми нашого дослідження актуальними $\epsilon$ висновки I. Беха [1], І. Білецької [2] та С. Шмалєй [6] щодо плідності використання моральних задач у процесі ціннісного освоєння дійсності. Результативність звернення до цих задач як засобу формування ціннісного ставлення до природи пояснюється тим, що екологічні задачі внаслідок свого етичного спрямування слід розглядати як один із основних різновидів моральних задач, що й дає підставу для активного їх використання в процесі формування в підлітків ціннісного ставлення до природи в освітньо-виховному процесі загальноосвітньої школи.

Ефективність застосування задач І.Білецька вбачає, по-перше, у тому, що вони виникають в реальній життєвій практиці дитини, як 
унікальні, суб'єктивно нові, що не відтворюють у точності жодну із ситуацій, які раніше відбувалися в іiі досвіді, по-друге, не мають переліку формальних рішень, який міг би бути запропонований вихованцеві педагогом. Оскільки моральні задачі не мають готового переліку дій «за правилом», увесь педагогічний процес будується так, щоб дитина могла самостійно знайти загальні принципи розв'язання поставлених проблем і способи втілення результатів у конкретній позитивній поведінці [2, с. 8].

Природно, що участь у розв'язанні таких задач надає ціннісній взаємодії підлітків з природою творчого характеру. За цих умов творча діяльність може бути представлена також як самостійне перенесення раніше засвоєних знань і умінь у нову ситуацію, бачення нової функції знайомого об'єкта, альтернативи розв'язування проблеми, комбінування засвоєних раніше способів діяльності та побудови нового оригінального способу розв'язування проблеми за наявності вже відомих.

Інтенсифікації розвитку внутрішнього тяжіння до спілкування 3 природою сприяє використання діалогової взаємодії у площині «учитель - підліток», «підліток - підліток» стосовно природи. Переваги iї використання в процесі формування ціннісних ставлень Л. Ломако вбачає в тому, що робота, організована як довірливе спілкування, «не дає змогу учневі залишатися пасивним у процесі оцінювання, байдужим до висловлювань інших; відбувається перетворення, перебудова особистості, змінюються ціннісні настанови [3, с. 165]». Ідеться про основні ознаки проблемного діалогу та його можливості і перспективи, адже завдяки йому підліток отримує змогу розібратися у власних поглядах, перевірити враження, проаналізувати почуття, поділитися своїми сумнівами, відстояти точку зору тощо. Як доводить В. Кушнір, основною ознакою проблемного діалогу є створення учителем простору для своїх вихованців 3 метою розв'язання проблеми разом 3 ними, а не за його вказівками. На період проблемної ситуації, стверджує учений, - здійснюється нова діалогічна спільність «учитель - учень (учні)», де вони спільно «живуть» і «переживають», відчувають невдачі та успіхи, спільно шукають істину. Процес із цільової орієнтації перетворюється в смислово-ціннісну орієнтацію. Ціль «ставиться», «сприймається», «досягається». Цінність «переживається», «сприймається». У такому розумінні ціль проблемної ситуації перетворюється в цінність $[4$, с. 11$] »$.

3 огляду на необхідність визначення шляхів розв'язання завдань нашого дослідження особливого значення набуває використання тих форм діалогової взаємодії, у процесі використання яких організується спільний пошук для обговорення моральних проблем взаємодії 3 112 
природою - добра, милосердя, гуманізму, відповідальності, чесності, совісті і т. ін. Ідеться не про те, щоб виробити остаточну точку зору на ці категорії, це неможливо, а про те, щоб допомогти підліткові визначитися у своєму ставленні до природи, розвинути здатність до екологічного судження й оцінки, вміння приймати рішення в непростих ситуаціях морального вибору.

Переконливою у цьому ракурсі $є$ думка А.Шемшуріна стосовно переваг використання виховуючого діалогу зі школярем на рівні його віку [5, с. 25-30]. Націлений на розв'язання етично-освітніх проблем, він у ситуації відповідної спрямованості безпосередньо слугує формуванню в підлітків ціннісного ставлення до природи. Завдяки його використанню створюються умови для збагачення процесу навчання методом, який дає змогу фіксувати і стимулювати оригінальні вияви особистісних екологічних вражень, емоційного забарвлення об'єктивної інформації про предмети і явища природного світу суб'єктивними асоціативними уявленнями учнів. У такий спосіб учитель, який реалізує екологічні цілі, не відокремлюючи педагогічний процес від безпосереднього життя учня, не поступається його інтересами, а намагається зрозуміти і врахувати їх. Установка на діалогічність спрямовує вчителя на пізнання внутрішнього світу своїх вихованців, унеможливлює ставлення до них як пасивних об'єктів педагогічного керівництва. Застосовуваний у процесі класної та позакласної навчально-виховної роботи з підлітками, діалог екологічного спрямування хвилює почуття, викликає сумніви, прагнення до пошуку істини, збуджує потяг до участі в природоохоронній діяльності. Ставлячи i обговорюючи питання про шляхи розв'язання актуальних екологічних проблем, учитель організує процес спілкування 3 природою як взаємодію екологічної інформації та суб'єктивної моделі іiі розуміння учнями. Причому це розуміння завжди $є$ активним внутрішнім екологічним процесом, лише за умови глибокого осмислення i творчої інтерпретації екологічної інформації в реципієнта складається своя позиція, розширюються рамки ціннісного пізнання й оцінки природного світу.

Особливе місце в системі екологічних ставлень особистості, як підтверджують результати нашого дослідження, посідає діалогова взаємодія, партнерами в якій $є$ об'єкти i явища природи. Вона здійснюється в руслі суб'єктифікації, що розглядається нами як процес i результат надання природним об'єктам здатності здійснювати специфічні суб'єктивні функції, внаслідок чого вони сприймаються особистістю як суб'єкти. Це створює умови для встановлення внутрішніх контактів підлітків із представниками природного світу, для 
сприйняття їх учнями як партнерів спільної діяльності і спілкування. Це відбувається тільки тоді, коли у реципієнта складається суб' єктивне ставлення до сприйнятого, потяг до власної інтерпретації природного об'єкта. Підліток розмовляє з уявним співбесідником, мотивує свою згоду чи незгоду з ним, тобто дає двоголосу відповідь як на власні думки, так і на думки суб'єктифікованого об'єкта. Це створює підгрунтя для піднесення ціннісного ставлення до природи на вищий щабель.

Наступним концептом $\epsilon$ те, що входження учня в уявний особистісний світ природного об'єкта передбачає наявність потреби в відкритості власного внутрішнього світу, особистісного довірливого спілкування, тобто відмови від готових упереджених оцінок, чутливості до мінливих станів представників природного світу.

Таким чином, у ситуації навіть мисленнєвої взаємодії підлітка 3 природничими об'єктами можуть виникати не тільки кількісні, але й якісні перетворення, долається відчуженість людини від природи, їх споконвічне протиставлення. Діалогічні стосунки, що склалися, орієнтують учнівську молодь на самовиявлення, самовизначення в своїх симпатіях і антипатіях, оскільки, вступаючи в взаємодію з нетотожною собі унікальністю «іншого», підліток відчуває власну унікальність, стає на шлях самореалізації.

Перспективи нашої подальшої науково-пошукової діяльності вивчення ставлення сім'ї та їі впливу на формування в учнівської молоді ціннісного ставлення до природи.

\section{Література:}

1. Бех І.Д. Особистісно зорієнтоване виховання: наук.-метод. посіб. - К.: ІЗМН, 1998. С. 48.

2. Білецька I.О. Виховання цінності іншої людини у молодших підлітків у процесі розв'язування моральних задач: автореф. дис... кандидата пед. наук / Ін-т проблеми виховання АПН України. К., 2004. 20 c.

3. Ломако Л. І. Проблема ціннісного пізнання в навчальній діяльності // Педагогіка і психологія.1997. №1. С. 160 - 165.

4. Кушнір В. Парадигма діалогу в професійній підготовці педагога. Шлях освіти. 2000. №4. С. 8-12.

5. Шемшурина А.А. Построение диалога со старшеклассниками // Управление школой. 2003. №27 (39). С. 25-30.

6. Шмалєй С.В. Система екологічної освіти в загальноосвітній школі в процесі вивчення предметів природничо-наукового циклу: монографія. Херсон, Літера, 2004. 364 с. 